University of Nebraska - Lincoln

DigitalCommons@University of Nebraska - Lincoln

$5-1986$

\title{
Restriction Endonuclease Activity Induced by PBCV-1 Virus Infection of a Chlorella-Like Green Alga
}

\author{
Yuannan Xia \\ University of Nebraska-Lincoln \\ Dwight Burbank \\ University of Nebraska-Lincoln \\ Lothar Uher \\ Bethesda Research Laboratories, Life Technologies, Inc., Gaithersburg, Maryland
}

Follow this and additional works at: https://digitalcommons.unl.edu/plantpathpapers

Part of the Plant Pathology Commons

Xia, Yuannan; Burbank, Dwight; and Uher, Lothar, "Restriction Endonuclease Activity Induced by PBCV-1 Virus Infection of a Chlorella-Like Green Alga" (1986). Papers in Plant Pathology. 117.

https://digitalcommons.unl.edu/plantpathpapers/117

This Article is brought to you for free and open access by the Plant Pathology Department at DigitalCommons@University of Nebraska - Lincoln. It has been accepted for inclusion in Papers in Plant Pathology by an authorized administrator of DigitalCommons@University of Nebraska - Lincoln. 


\title{
Restriction Endonuclease Activity Induced by PBCV-1 Virus Infection of a Chlorella-Like Green Alga $\dagger$
}

\author{
YUANNAN XIA, ${ }^{1}$ DWIGHT E. BURBANK, ${ }^{1}$ LOTHAR UHER, ${ }^{2}$ DIETMAR RABUSSAY ${ }^{2}$ \\ AND JAMES L. VAN ETTEN ${ }^{1 *}$ \\ Department of Plant Pathology, University of Nebraska, Lincoln, Nebraska 68583-0722, ${ }^{1}$ and Molecular Biology \\ Research and Development, Bethesda Research Laboratories, Life Technologies, Inc., Gaithersburg, Maryland 20877 ${ }^{2}$
}

Received 2 December 1985/Accepted 24 January 1986

\begin{abstract}
An enzyme was isolated from a eucaryotic, Chlorella-like green alga infected with the virus PBCV-1 which exhibits type II restriction endonuclease activity. The enzyme recognized the sequence GATC and cleaved DNA $5^{\prime}$ to the G. Methylation of deoxyadenosine in the GATC sequence inhibited enzyme activity. In vitro the enzyme cleaved host $C$ hlorella nuclear DNA but not viral DNA because host DNA contains GATC and PBCV-1 DNA contains $\mathbf{G}^{\mathbf{m}} \mathbf{A}$ TC sequences. PBCV-1 DNA is probably methylated in vivo by the PBCV-1-induced methyltransferase described elsewhere (Y. Xia and J. L. Van Etten, Mol. Cell. Biol. 6:1440-1445). Restriction endonuclease activity was first detected 30 to $60 \mathrm{~min}$ after viral infection; the appearance of enzyme activity required de novo protein synthesis, and the enzyme is probably virus encoded. Appearance of enzyme activity coincided with the onset of host DNA degradation after PBCV-1 infection. We propose that the PBCV-1induced restriction endonuclease participates in host DNA degradation and is part of a virus-induced restriction and modification system in PBCV-1-infected Chlorella cells.
\end{abstract}

We have previously characterized a large polyhedral virus, $P B C V-1$, which infects and replicates in a unicellular, eucaryotic Chlorella-like green alga, strain NC64A. The virus contains a large double-stranded DNA genome (ca. 300 kilobase pairs as estimated by summing restriction fragments), at least 50 structural proteins, and a lipid component $(22,29)$. The virus can be assayed by plaque formation, and milligram quantities can be produced in culture $(27,28)$. PBCV-1 infection is synchronous, and progeny virus is first released at 3 to $4 \mathrm{~h}$ postinfection; by 6 to $8 \mathrm{~h}$ virus release is complete. The virus has a burst size of 200 to 350 PFU per cell (28).

Studies on DNA synthesis after PBCV-1 infection established that viral DNA synthesis begins about 45 min after infection; host DNA synthesis ceases immediately after infection, and host nuclear and chloroplast DNAs are degraded beginning about $60 \mathrm{~min}$ after infection (26). Base analyses of Chlorella nuclear and PBCV-1 DNAs revealed that the host DNA contains $21 \%$ 5-methyldeoxycytidine $\left(\mathrm{m}^{5} \mathrm{dC}\right)$ and $0.6 \% \mathrm{~N}^{6}$-methyldeoxyadenosine $\left(\mathrm{m}^{6} \mathrm{dA}\right) ; \mathrm{PBCV}$ 1 DNA has $1.9 \% \mathrm{~m}^{5} \mathrm{dC}$ and $1.5 \% \mathrm{~m}^{6} \mathrm{dA}(30)$. However, at least some, if not all, of the viral methylated bases are located in different sequences than those in the host DNA. For example, PBCV-1 DNA contains $\mathrm{m}^{6} \mathrm{dA}$ in the sequence $G^{m} A T C$, whereas the host DNA does not (30). These observations suggest that $\mathrm{PBCV}$-1-infected cells contain a methyltransferase which recognizes DNA sequences distinct from those recognized by the host enzyme(s). Such an enzyme is described in the following paper (34). Furthermore, we suspected that a virus-encoded nuclease might be involved in the degradation of the host DNA. Consequently, PBCV-1-infected cells were examined for an enzyme which degrades host DNA but not viral DNA. This report describes

\footnotetext{
* Corresponding author.

$\dagger$ Published with the approval of the Director as paper no. 7950, Journal Series, Nebraska Agricultural Experiment Station.
}

the characterization of an apparently virus-encoded restriction endonuclease.

\section{MATERIALS AND METHODS}

Growth and infection of the alga. The exsymbiont Chlorella-like alga NC64A, originally isolated from Paramecium bursaria (11), was obtained from L. Muscatine at the University of California, Los Angeles. The alga was grown in continuous light on MBBM medium as described previously (28). The production and purification of PBCV-1 have also been described previously (28). Chlorella cells $\left(1 \times 10^{7}\right.$ to 2 $\times 10^{7} / \mathrm{ml}$ ) were infected with PBCV-1 at a multiplicity of infection of 5 , and cells were collected by centrifugation and either used immediately or frozen at $-80^{\circ} \mathrm{C}$.

Chlorella cells were inactivated in some experiments by placing $80 \mathrm{ml}$ of actively growing Chlorella cells $\left(10^{7} / \mathrm{ml}\right)$ in a 23-cm-diameter glass baking dish and positioning it $30 \mathrm{~cm}$ below a $15-W$ Westinghouse germicidal Sterilamp (number G15T8). The cells were continuously mixed with a stirring bar during the 10-min UV treatment. Colony formation was completely inhibited by this 10 -min exposure to UV light, and endogenous host nucleic acid and protein syntheses were reduced to nearly background levels (J. Van Etten, D. Burbank, and R. Meints, submitted for publication).

Enzyme extracts. Infected ( $3 \mathrm{~h}$ postinfection) and uninfected cells harvested from 4-liter cultures were suspended in $15 \mathrm{ml}$ of $0.01 \mathrm{M}$ Tris hydrochloride ( $\mathrm{pH} \mathrm{7.9)-0.01} \mathrm{M}$ 2-mercaptoethanol-50 $\mu \mathrm{g}$ of phenylmethylsulfonyl fluoride per ml plus $10 \mathrm{~g}$ of $0.3-\mathrm{mm}$ glass beads and homogenized for $60 \mathrm{~s}$ at $4,000 \mathrm{rpm}$ with a Bronwill MSK mechanical homogenizer with cooling from a $\mathrm{CO}_{2}$ tank. The homogenate was centrifuged at $10,000 \times g$ for $20 \mathrm{~min}$; the supernatant was frozen at $-20^{\circ} \mathrm{C}$, thawed at $4^{\circ} \mathrm{C}$, and centrifuged at $16,000 \times$ $g$ for $30 \mathrm{~min}$. This freeze-thaw and centrifugation treatment precipitated most of the green color and yielded a clear supernatant fraction (fraction 1). The following components 
were added per milliliter of supernatant: $0.5 \mathrm{ml}$ of denatured salmon sperm DNA at $5 \mathrm{mg} / \mathrm{ml}$ in $0.01 \mathrm{M}$ Tris hydrochloride (pH 7.9), $0.001 \mathrm{M}$ EDTA, $0.6 \mathrm{~g}$ of polymer concentrate $(7 \%$ [wt/wt] dextran T500, 28\% [wt/wt] polyethylene glycol 6000 [21]), and $0.64 \mathrm{ml}$ of $4 \mathrm{M} \mathrm{NaCl}$. The samples were mixed thoroughly for $5 \mathrm{~min}$ and then centrifuged for $10 \mathrm{~min}$ at 5,000 $\times g$. The upper layer was dialyzed overnight with three changes of $0.01 \mathrm{M} \mathrm{KPO}_{4}(\mathrm{pH} 7.4)-0.5 \mathrm{mM}$ sodium EDTA-7 $\mathrm{mM} 2$-mercaptoethanol-5\% glycerol at $4^{\circ} \mathrm{C}$ (fraction 2$)$. The samples were either assayed for enzyme activity at this stage or diluted to $200 \mathrm{ml}$ with $0.01 \mathrm{M} \mathrm{KPO}_{4}(\mathrm{pH}$ 7.4) and chromatographed on a phosphocellulose (Whatman P11) column $\left(1\right.$ by $10 \mathrm{~cm}$ ) equilibrated with $0.01 \mathrm{M} \mathrm{KPO}_{4}$ buffer (pH 7.4). The column had a flow rate of $5 \mathrm{ml} / \mathrm{h}$ at $4^{\circ} \mathrm{C}$, and protein was eluted stepwise with 5 -ml portions of $0.01 \mathrm{M}$ $\mathrm{KPO}_{4}$ (pH 7.4) containing $\mathrm{KCl}$ from 0 to $1.0 \mathrm{M}$ in $0.1 \mathrm{M}$ increments. Fractions of $2.5 \mathrm{ml}$ were collected, and those containing enzyme activity $(0.5$ to $0.7 \mathrm{M} \mathrm{KCl})$ were pooled (fraction 3). The enzyme was precipitated with $70 \%$ $\left(\mathrm{NH}_{4}\right)_{2} \mathrm{SO}_{4}$, taken up in $10 \mathrm{mM}$ Tris hydrochloride $(\mathrm{pH}$ 7.5)-100 mM KCl-0.1 mM sodium EDTA-1 mM dithiothreitol-500 $\mu \mathrm{g}$ of bovine serum albumin per $\mathrm{ml}-50 \%(\mathrm{vol} / \mathrm{vol})$ glycerol (fraction 4$)$, and stored at $-20^{\circ} \mathrm{C}$. All of these steps were performed at $4^{\circ} \mathrm{C}$.

Enzyme assays. Unless noted otherwise, the enzyme was assayed at $37^{\circ} \mathrm{C}$ for $2 \mathrm{~h}$ in $20-\mu \mathrm{l}$ reaction mixtures containing $10 \mathrm{mM}$ Tris hydrochloride ( $\mathrm{pH} 7.5), 10 \mathrm{mM} \mathrm{MgCl}_{2}, 50 \mathrm{mM}$ $\mathrm{KCl}, 1 \mathrm{mM}$ dithiothreitol, $1 \mu \mathrm{g}$ of substrate DNA, and 2.5 to $5 \mu$ l of enzyme extract. In some experiments DNA was digested in core buffer ( $50 \mathrm{mM}$ Tris hydrochloride [pH 8.0], $\left.10 \mathrm{mM} \mathrm{MgCl}_{2}, 50 \mathrm{mM} \mathrm{NaCl}\right)$. The reaction products were electrophoresed either on $1.2 \%$ agarose gels in $0.08 \mathrm{M}$ Tris phosphate- $0.008 \mathrm{M}$ sodium EDTA (pH 8.5) or on 7.5 to $15 \%$ linear gradient polyacrylamide gels in $0.04 \mathrm{M}$ Tris acetate (pH 8.3) $-0.02 \mathrm{M}$ sodium acetate- $0.002 \mathrm{M}$ sodium EDTA (10). DNA was stained with ethidium bromide and viewed under UV light. One unit of enzyme is defined in Table 1, footnote $a$.

Southern blot analysis. After agarose gel electrophoresis, DNA fragments were transferred to nitrocellulose and hybridized to a ${ }^{32}$ P-labeled PBCV-1 DNA BamHI fragment, B6 (30). Transfer and hybridization conditions were according to the methods of Wahl et al. (31) except that dextran sulfate was omitted from the hybridization mixture. The B6 fragment was labeled with $\left[\alpha-{ }^{32} \mathrm{P}\right] \mathrm{dCTP}(800 \mathrm{Ci} / \mathrm{mol}$; New England Nuclear Corp., Boston, Mass.), using a nick translation kit (Bethesda Research Laboratories Inc., Gaithersburg, Md.). Filters were exposed to Kodak XAR-5 film at $-80^{\circ} \mathrm{C}$ with a Du Pont Cronex intensifying screen.

Ligation and recleaving of DNA restriction fragments. Three sets of DNA restriction fragments were prepared by digesting simian virus 40 (SV40) DNA with MboI, Sau3AI, or the PBCV-1-induced restriction endonuclease, followed by phenol deproteinization and ethanol precipitation. The DNAs were dissolved in $10 \mathrm{mM}$ Tris hydrochloride $(\mathrm{pH}$ 7.2) $-0.1 \mathrm{mM}$ EDTA-5 mM NaCl at a concentration of 0.4 $\mu \mathrm{g} / \mu \mathrm{l}$. Ligation reactions were incubated at $22^{\circ} \mathrm{C}$ for $4 \mathrm{~h}$ in $20-\mu$ l reaction mixtures containing $66 \mathrm{mM}$ Tris hydrochloride ( $\mathrm{pH} 7.6$ ), $66 \mathrm{mM} \mathrm{MgCl}_{2}, 10 \mathrm{mM}$ dithiothreitol, $0.4 \mathrm{mM}$ ATP, 5 U of T4 DNA ligase (Bethesda Research Laboratories), and two different sets of SV40 DNA restriction fragments $(2 \mu \mathrm{g}$ of DNA per set). Each reaction mixture was then divided in half. One half was added to $10 \mu$ l of water and $2 \mu$ l of stop mix $(0.1 \%$ bromophenol blue, 0.1 M EDTA, $1 \%$ sodium dodecyl sulfate, $50 \%$ glycerol). The other half was heated at $65^{\circ} \mathrm{C}$ for $10 \mathrm{~min}$ and added to $2 \mu \mathrm{l}$ of $10 \times$ core buffer-2 $\mu$ l (0.5 units) of the PBCV-1-induced restriction endonuclease $-6 \mu \mathrm{l}$ of water. After a $2-\mathrm{h}$ incubation at $37^{\circ} \mathrm{C}$, the reaction was stopped by adding $2 \mu$ l of stop mix. All DNA products from the ligation and ligation-recleaving reactions were electrophoresed on $1.2 \%$ agarose gels.

Determination of restriction endonuclease cleavage site by DNA sequencing. Dideoxy chain termination sequencing reactions were carried out with the single-stranded bacteriophage vector M13mp19, the 15-base universal sequencing primer, and ${ }^{35} \mathrm{~S}$-substituted deoxyadenosine $5^{\prime}-[\alpha$ thio]triphosphate $\left(\left[\alpha-{ }^{35} S\right] \mathrm{dATP}\right)$, using the method of Sanger et al. (20) as described in the M13 Dideoxy Sequencing Manual of Bethesda Research Laboratories. The sequencing primer contains a sequence complementary to the region about 40 nucleotides preceding the GATC sequence in the BamHI site of the multiple restriction region of M13mp19 DNA.

DNA-primed synthesis products used for restriction endonuclease digestions were prepared in $50 \mu \mathrm{l}$ of reaction mixture containing $25 \mu \mathrm{M}$ each dCTP, dGTP, and dTTP, $42.6 \mu \mathrm{Ci}$ of $\left[\alpha^{-35} \mathrm{~S}\right] \mathrm{dATP}(650 \mathrm{mCi} / \mu \mathrm{mol}$; Amersham Corp., Arlington Heights, Ill.), $3.5 \mathrm{U}$ of Escherichia coli DNA polymerase I (Klenow fragment), $1.97 \mu \mathrm{g}$ of M13mp19+strand DNA preannealed with $8 \mathrm{ng}$ of sequencing primer, 4.3 $\mathrm{mM}$ dithiothreitol, $55 \mathrm{mM} \mathrm{NaCl}, 7.7 \mathrm{mM} \mathrm{MgCl}$, and $7.7 \mathrm{mM}$ Tris hydrochloride ( $\mathrm{pH} 7.5$ ). The mixture was incubated for $15 \mathrm{~min}$ at $30^{\circ} \mathrm{C}$, and then $10 \mu \mathrm{l}$ of $0.5 \mathrm{mM}$ dATP was added, and the incubation continued for another $15 \mathrm{~min}$ at $30^{\circ} \mathrm{C}$. The mixture was heated to $65^{\circ} \mathrm{C}$ for $15 \mathrm{~min}$ and cooled on ice, and 2.5- $\mu$ l samples were removed and incubated at $37^{\circ} \mathrm{C}$ for 30 min with either $5 \mathrm{U}$ each of $\mathrm{MboI}$ and $\mathrm{Sau} 3 \mathrm{AI}$ or $0.5 \mathrm{U}$ of the $\mathrm{PBCV}$-1-induced restriction endonuclease in a total volume of $6 \mu$ l containing $42 \mathrm{mM}$ Tris hydrochloride ( $\mathrm{pH} \mathrm{8.0)}, 8.3$ $\mathrm{mM} \mathrm{MgCl} 2$, and $42 \mathrm{mM} \mathrm{NaCl}$. The reactions were terminated by adding $10 \mu \mathrm{l}$ of formamide-dye mix $(0.1 \%$ xylene cyanol FF, $0.1 \%$ bromophenol blue, $10 \mathrm{mM}$ sodium EDTA, 95\% deionized formamide). The remainder of the DNA synthesis reaction mixture was extracted with phenol in the presence of $1 \mu \mathrm{g}$ of carrier DNA, precipitated with ethanol, washed, dried, and suspended in water. The DNA was digested with the three restriction endonucleases as described above for the samples not phenol extracted before restriction enzyme cleavage. All samples were electrophoresed on a $8 \%$ polyacrylamide $-7 \mathrm{M}$ urea sequencing gel adjacent to the products of a set of dideoxynucleotide DNA sequencing reactions. The gel was dried on Whatman $3 \mathrm{MM}$ paper and autoradiographed with Kodak XAR-5 film.

Sources of DNAs. Host nuclear and PBCV-1 DNAs were isolated as described previously (30). Unmethylated pBR322 plasmid DNAs, containing either a 16-kilobase-pair BamHI PBCV-1 DNA insert (fragment B6) (plasmid pLG164) or without B6, were prepared by growing the plasmids in $E$. coli GM2163 as described previously (30). This strain of $E$. coli, kindly provided by Martin Marinus, lacks both dam and $\mathrm{dcm}$ methyltransferase activities (15). Unmethylated lambda DNA was purchased from New England Nuclear Corp. SV40 DNA (form I) isolated from BSC-1 monkey cells, adenovirus type 2 DNA isolated from HeLa cells, $\phi$ X174 DNA (form I), M13mp19 DNA, and universal sequencing primer were obtained from Bethesda Research Laboratories.

Other procedures. The Chlorella DNA from virus-infected cells was analyzed by equilibrium sedimentation on $\mathrm{CsCl}$ gradients as described previously (26). The DNAs were treated with dam methylase (New England BioLabs, Inc., Beverly, Mass.) or with restriction endonucleases according to the protocols provided by the suppliers and electropho- 
resed on $1.2 \%$ agarose gels. Nonspecific DNases were assayed by previously described procedures $(3,5,19)$.

\section{RESULTS}

Restriction endonuclease activity. We previously reported that PBCV-1 infection resulted in the degradation of the host nuclear and chloroplast DNA beginning at about $1 \mathrm{~h}$ after infection (26). To determine whether a new nonspecific DNase(s) appeared in cells after viral infection, cell extracts were prepared from uninfected and PBCV-1-infected cells ( 3 $h$ postinfection) and electrophoresed on both denaturing and nondenaturing polyacrylamide gels impregnated with host DNA, PBCV-1 DNA, or unmethylated lambda DNA. After electrophoresis the gels were soaked in renaturing buffer for periods up to $24 \mathrm{~h}$ and then stained with ethidium bromide. Five bands (i.e., nonstaining regions) indicative of DNase activity were detected in cell extracts from both uninfected and virus-infected cells with all three DNAs; the intensity of the bands was also identical for the two cell extracts (data not shown). This suggested that a new enzyme(s) with either nonspecific DNase or specific DNase activity was not induced after PBCV-1 infection.

To determine whether PBCV-1-infected cells contained a restriction endonuclease, enzyme extracts were prepared from both uninfected and 3-h-infected cells and chromatographed on phosphocellulose columns. The extract from virus-infected cells (Fig. 1) but not from uninfected cells

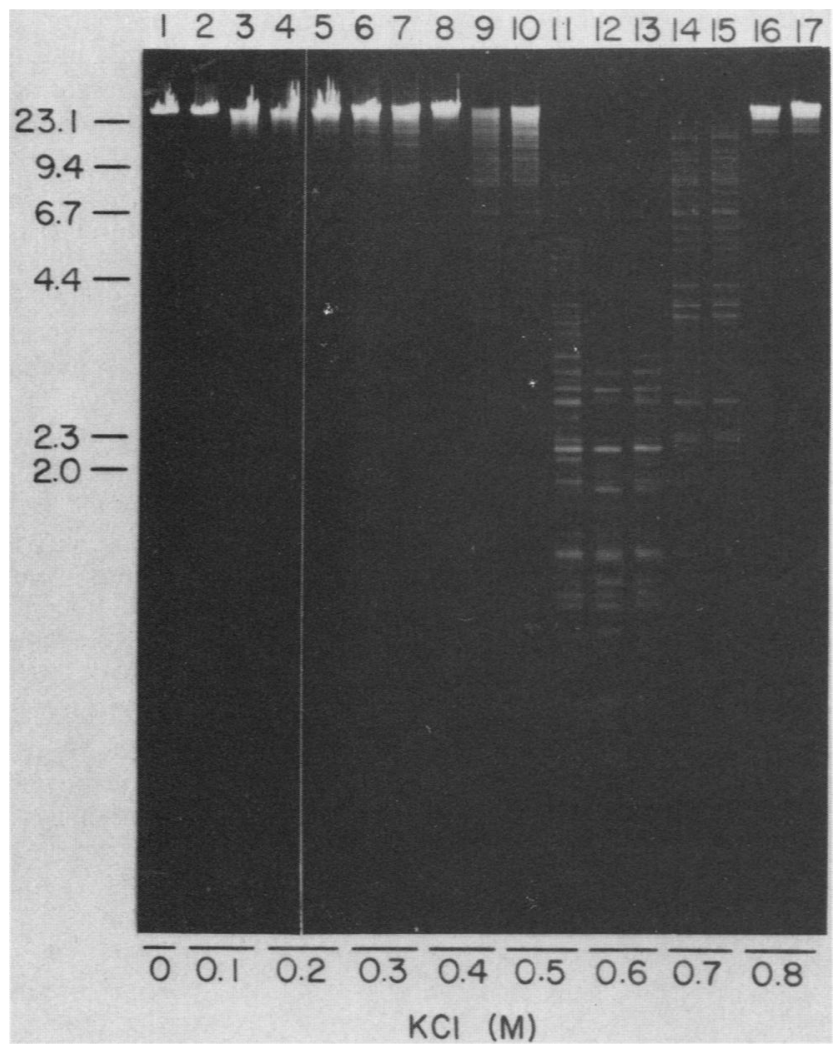

FIG. 1. Phosphocellulose column chromatography of an enzyme extract prepared from PBCV-1-infected Chlorella cells at $3 \mathrm{~h}$ postinfection. Protein $(33 \mathrm{mg})$ was applied to the column and eluted stepwise with 0 to $0.8 \mathrm{M} \mathrm{KCl}$. Fractions $(2.5 \mathrm{ml})$ were collected, and $5 \mu \mathrm{l}$ of each fraction was incubated with $1 \mu \mathrm{g}$ of unmethylated lambda DNA at $37^{\circ} \mathrm{C}$ for $2 \mathrm{~h}$. The DNAs were electrophoresed on $1.2 \%$ agarose gels. Numbers on left are in kilobase pairs.

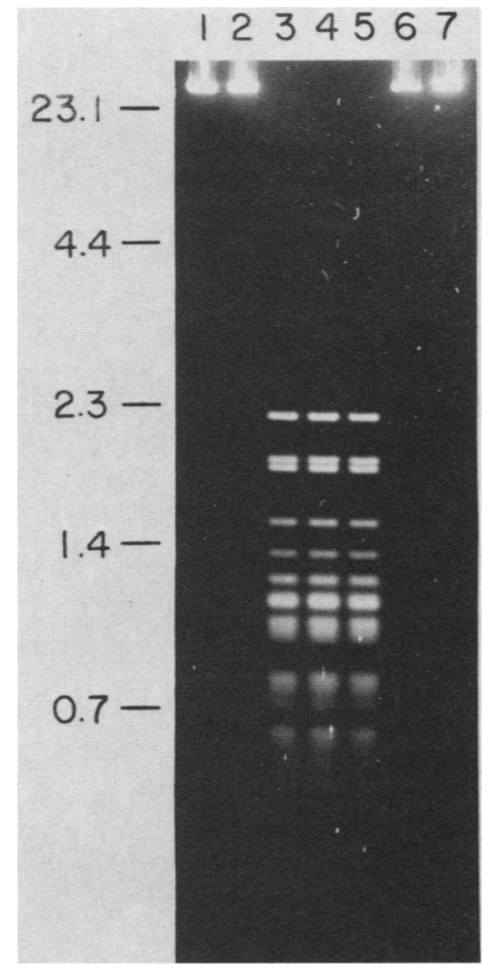

FIG. 2. Ability of an enzyme extract (fraction 4) from 3-hinfected Chlorella cells to degrade unmethylated lambda DNA. Lanes: 1, untreated lambda DNA; 2, lambda DNA after incubation with an enzyme extract from uninfected cells; 3 , lambda DNA after a 2-h incubation with an enzyme extract from 3-h-infected cells; 4, the same as lane 3 except that incubation was for $16 \mathrm{~h} ; 5$, the same as lane 4 but incubated for an additional $2 \mathrm{~h}$ with a second aliquot of enzyme; 6 , the same as lane 3 but $\mathbf{M g}^{2+}$ was omitted from the assay; 7 , the same as lane 3 except that the enzyme extract was heated to $65^{\circ} \mathrm{C}$ for $10 \mathrm{~min}$ before adding it to the DNA. The DNAs were electrophoresed on a $1.2 \%$ agarose gel. Numbers on the left are in kilobase pairs.

(data not shown) contained enzyme activity eluting at 0.5 to $0.7 \mathrm{M} \mathrm{KCl}$ which cleaved unmethylated lambda DNA into distinct fragments. It should be noted that the differences in DNA fragment patterns seen in Fig. 1 (e.g., compare lanes 12 and 14) and some of the other figures (e.g., see Fig. 9B) are not the result of a second restriction endonuclease activity but simply reflect incomplete digestion of the DNA. That is, if more enzyme extract was added or these samples were incubated for longer times, the DNA cleavage patterns were identical. Fractions 11 to 14 (Fig. 1) were pooled as described in Materials and Methods (fraction 4) and analyzed further.

The enzyme cleaved unmethylated lambda DNA into a number of discrete bands during a 2-h incubation (Fig. 2, lane 3). If the DNA was incubated with the enzyme for $16 \mathrm{~h}$ (lane 4) or if the DNA was treated with a second aliquot of enzyme for two additional hours after a 16-h incubation (lane 5), no additional DNA fragments appeared. Thus, the enzyme cleaved lambda DNA at a limited number of sites. Heating the enzyme to $65^{\circ} \mathrm{C}$ for $10 \mathrm{~min}$ destroyed the enzyme activity (Fig. 2, lane 7).

The activity of the enzyme was not stimulated by ATP or $S$-adenosylmethionine (data not shown) but was totally dependent on $\mathrm{Mg}^{2+}$ (Fig. 2, lane 6). The enzyme was most active in $10 \mathrm{mM} \mathrm{Mg}^{2+}-0.01 \mathrm{M}$ Tris hydrochloride ( $\mathrm{pH}$ 
TABLE 1. Purification of PBCV-1-induced restriction endonuclease

\begin{tabular}{lcccc}
\hline $\begin{array}{c}\text { Fraction no. } \\
\text { and steps }\end{array}$ & $\begin{array}{c}\text { Total } \\
\text { vol }(\mathrm{ml})\end{array}$ & $\begin{array}{c}\text { Total } \\
\text { protein }(\mathrm{mg})\end{array}$ & $\begin{array}{c}\text { Total } \\
\text { units }\end{array}$ & $\begin{array}{c}\text { Sp act } \\
(\mathrm{U} / \mathrm{mg} \text { of } \\
\text { protein }\end{array}$ \\
\hline 1. Cell extract & 15 & 81.6 & $\mathrm{ND}^{b}$ & $\mathrm{ND}^{b}$ \\
2. PEG-dextran & 40 & 32.8 & 40,000 & 1,220 \\
3. Phosphocellulose & 7.0 & $0.35^{d}$ & 14,000 & 40,000 \\
4. Ammonium sulfate & 1.0 & $0.05^{d}$ & 5,000 & 100,000 \\
\hline
\end{tabular}

${ }^{a}$ Unit definition: $1 \mathrm{U}$ is defined as the amount of enzyme required to completely digest $1.0 \mu \mathrm{g}$ of unmethylated lambda DNA in $1 \mathrm{~h}$ at $37^{\circ} \mathrm{C}$ in $20 \mu \mathrm{l}$ of assay buffer.

${ }^{b}$ ND, Not determined.

c PEG, Polyethylene glycol.

${ }^{d}$ Protein concentration of fractions 3 and 4 was estimated from the density of protein bands stained with Coomassie brilliant blue on sodium dodecyl sulfate-polyacrylamide gel.

7.5)-50 $\mathrm{mM} \mathrm{KCl}$. The temperature optimum was $37^{\circ} \mathrm{C}$. The enzyme could be stored at $-20^{\circ} \mathrm{C}$ in buffer containing $50 \%$ glycerol and $500 \mu \mathrm{g}$ of bovine serum albumin per $\mathrm{ml}$ for at least 1 year without loss of activity. The purification of the enzyme is summarized in Table 1 . The specific activity of the partially purified enzyme was estimated to be about $10^{5}$ $\mathrm{U} / \mathrm{mg}$ of protein.

Specificity of DNA recognition and cleavage. The specific base sequence that the PBCV-1-induced restriction endonuclease recognizes was examined by using unmethylated plasmid pBR322 DNA as a substrate. pBR322 DNA was cleaved into eight fragments larger than 140 base pairs in length by the virus-encoded enzyme (Fig. 3, lane 4). These fragments were identical in size to those produced by the bacterial restriction endonuclease $\mathrm{MboI}$ (Fig. 3, lane 3). Since $M b o I$ recognizes the sequence GATC, the PBCV-1induced restriction endonuclease most likely recognizes and cleaves in the same sequence.

The cleavage patterns obtained with two other DNAs, adenovirus type 2 DNA and SV40 DNA, also were identical for the PBCV-1-induced restriction endonuclease and $\mathrm{MboI}$. $\phi X 174$ DNA (form I), which does not contain a GATC sequence, was not cleaved by either of the two enzymes (data not shown). Therefore, the recognition sequence of the PBCV-1 restriction endonuclease must be GATC.

The precise site of DNA cleavage by the PBCV-1 restriction endonuclease was established by two methods. First, two different sets of SV40 DNA restriction fragments generated by digestion with MboI, Sau3AI, or the PBCV-1induced restriction endonuclease were ligated. Each set of DNA fragments hybridized and ligated well with the other two sets of DNA fragments (Table 2). This suggests that the PBCV-1-induced restriction endonuclease cleaves DNA at the same position as $M b o I$ and Sau3AI, i.e., $5^{\prime}$ to the $\mathrm{G}$ in the GATC sequence. In addition, the high efficiency of ligation indicates that the PBCV-1-induced restriction endonuclease generates 5'-phosphate termini like most other restriction endonucleases.

Second, the site of cleavage was confirmed by sequencing stretches of M13mp19 DNA containing a GATC recognition site and determining the position of the fragment generated by the PBCV-1-induced restriction endonuclease. The BamHI site of the multiple restriction region of $\mathrm{M} 13 \mathrm{mp} 19$ DNA harbors a GATC sequence, which is recognized by $M b o I, S a u 3 A$, and the PBCV-1-induced restriction endonuclease. As shown in Fig. 4 (compare lanes $C$ to $T$ and 5 to 7), a major band in lanes 5 to 7 coincides with the $G$ just below the sequence GATC. Thus, the PBCV-1-induced restriction endonuclease cleaves $5^{\prime}$ to the $\mathrm{G}$ in the GATC sequence, exactly as does $\mathrm{MboI}$ and Sau3AI. The fainter, fastermigrating fragments in lanes 5 to 7 (and lanes 2 to 4) were due to partial degradation of the restriction fragments, probably by contaminating exonuclease (note that a large excess of restriction endonucleases was used). The $65^{\circ} \mathrm{C}$ treatment, which does not completely inactivate $E$. coli DNA polymerase I (Klenow fragment), resulted in an end-filling reaction during the restriction endonuclease digestion. The appearance of four additional, slower-migrating bands on the top of the $G$ band (lanes 2 to 4 ) provides additional support for the generation of a 4-nucleotide-long sticky end with the sequence 5 '-GATC-3'. Thus, the recognition and cleavage site for the PBCV-1-induced restriction endonuclease is:

$$
\begin{gathered}
\downarrow \\
5^{\prime}-\text { pGATC }-3^{\prime} \\
3^{\prime}-\text { CTAGp }-5^{\prime} \\
\uparrow
\end{gathered}
$$

Effect of methylated bases on enzyme activity. Chlorella nuclear DNA (Fig. 5A, lane 2) but not PBCV-1 DNA (lane 4)

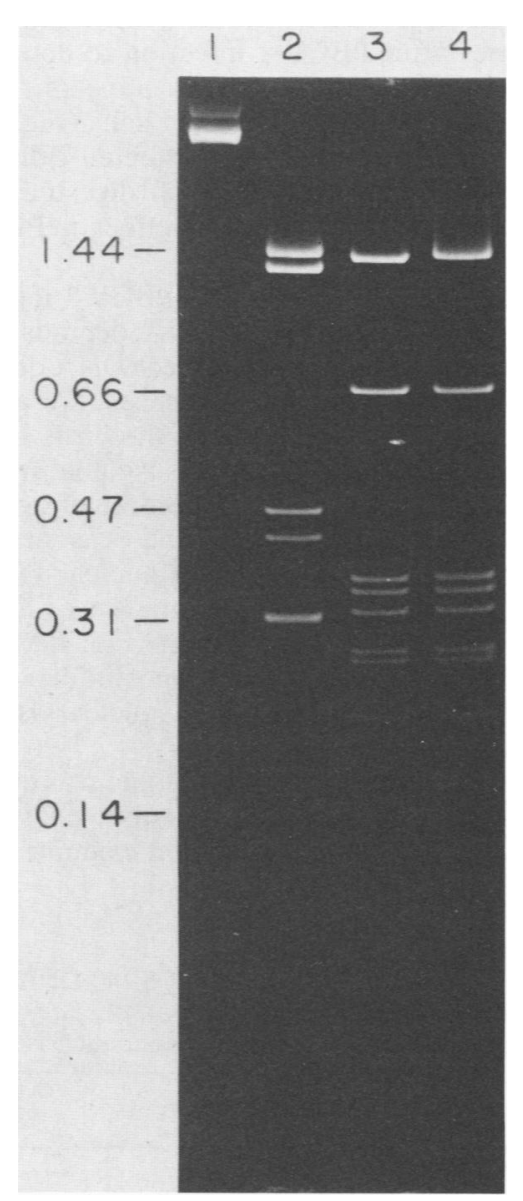

FIG. 3. Ability of PBCV-1-induced restriction endonuclease to degrade unmethylated plasmid pBR322 DNA. Lanes: 1 , untreated DNA; 2, DNA treated with TaqI; 3, DNA treated with MboI; 4, DNA treated with PBCV-1 restriction endonuclease. Note: the sizes of the DNA fragments in lanes 3 and 4 are identical. The DNAs were electrophoresed on a 7.5 to $15 \%$ linear gradient polyacrylamide gel. Numbers on the left are in kilobase pairs. 
was cleaved by the PBCV-1-induced restriction endonuclease. To determine whether the resistance of PBCV-1 DNA to cleavage was due to the presence of $\mathrm{m}^{5} \mathrm{dC}$ or $\mathrm{m}^{6} \mathrm{dA}$ or both, a 16-kilobase-pair BamHI PBCV-1 DNA fragment (B6) was cloned in the plasmid pBR322 (plasmid pLG164) and grown in a dcm dam E. coli strain. After growth in this host, the B6 DNA fragment was cleaved by the PBCV-1-induced restriction endonuclease (Fig. 5B, lane 4), whereas the same fragment in genomic PBCV-1 DNA was resistant (Fig. 5B, lane 8). Thus, $\mathrm{m}^{5} \mathrm{dC}$ or $\mathrm{m}^{6} \mathrm{dA}$ or both in the PBCV-1 DNA protect the DNA from enzyme digestion.

We previously reported that PBCV-1 DNA contains $\mathrm{m}^{6} \mathrm{dA}$ in the sequence GATC, whereas host DNA lacks $\mathrm{m}^{6} \mathrm{dA}$ in this sequence (30). Since the PBCV-1-induced enzyme cleaves at GATC sequences, it seemed likely that $\mathrm{m}^{6} \mathrm{dA}$ in this sequence might inhibit the PBCV-1-induced enzyme. To test this possibility, unmethylated lambda DNA was methylated with the $E$. coli dam methylase; dam methylase specifically methylates deoxyadenosines in the GATC sequence $(7,9,14)$. Methylation of lambda DNA with the dam methylase prevented cleavage by the PBCV-1-induced enzyme (Fig. 6, compare lanes 2 and 4). Thus, the PBCV-1induced enzyme cleaves GATC but not $\mathrm{G}^{\mathrm{m}} \mathrm{ATC}$.

Correlation between host DNA degradation and appearance of PBCV-1-induced restriction endonuclease. Chlorella and PBCV-1 DNAs were treated with enzyme extracts prepared at various times after PBCV-1 infection to determine when the restriction endonuclease activity appears. Enzyme extracts from 1-, 2-, 3-, and 4-h-infected cells (Fig. 7A, lanes 3 to 6 , respectively) but not from uninfected cells (lane 1) or from zero-time-infected cells (lane 2) digested host DNA. The 1- to 4-h enzyme extracts had no effect on PBCV-1 DNA (Fig. 7B).

We demonstrated previously that PBCV-1 infection leads to host nuclear and chloroplast DNA degradation in vivo (26). To determine whether host nuclear DNA degradation in vivo required de novo protein syntheses, we added cycloheximide either at the same time as the virus or at various times after infection. Total DNA was isolated from an equal number of infected cells either at the time of cycloheximide addition or at $4 \mathrm{~h}$ postinfection and was centrifuged to equilibrium on $\mathrm{CsCl}$ gradients. Host nuclear DNA was not degraded to any extent if cycloheximide was added during the first $30 \mathrm{~min}$ after viral infection (Fig. 8A). However, addition of cycloheximide at 60 min postinfection permitted substantial degradation of the host nuclear DNA by $4 \mathrm{~h}$ postinfection.

In a parallel experiment, cycloheximide was added to cells at various times after PBCV-1 infection; enzyme extracts were prepared at $4 \mathrm{~h}$ postinfection and examined for restric-

TABLE 2. Ligation and recleavage of SV40 DNA restriction fragments generated by cleavage with $\mathrm{MboI}$, Sau3AI, and the PBCV-1-induced restriction endonuclease ${ }^{a}$

\begin{tabular}{lcc}
\hline DNA fragments & \% Ligation efficiency & $\begin{array}{c}\text { \% Recleavage } \\
\text { efficiency }\end{array}$ \\
\hline PBCV-1-MboI & $>90$ & 100 \\
PBCV-1-Sau3AI & $>90$ & 100 \\
Sau3AI-MboI & $>85$ & 100 \\
\hline
\end{tabular}

${ }^{a}$ Separate samples of SV40 DNA were digested with the restriction endonucleases MboI, Sau3AI, and the PBCV-1-induced enzyme. The DNA fragments were purified and ligated in pairs. Ligated DNA was then digested with the PBCV-1 enzyme. The degree of ligation and recleavage were judged by visual inspection.

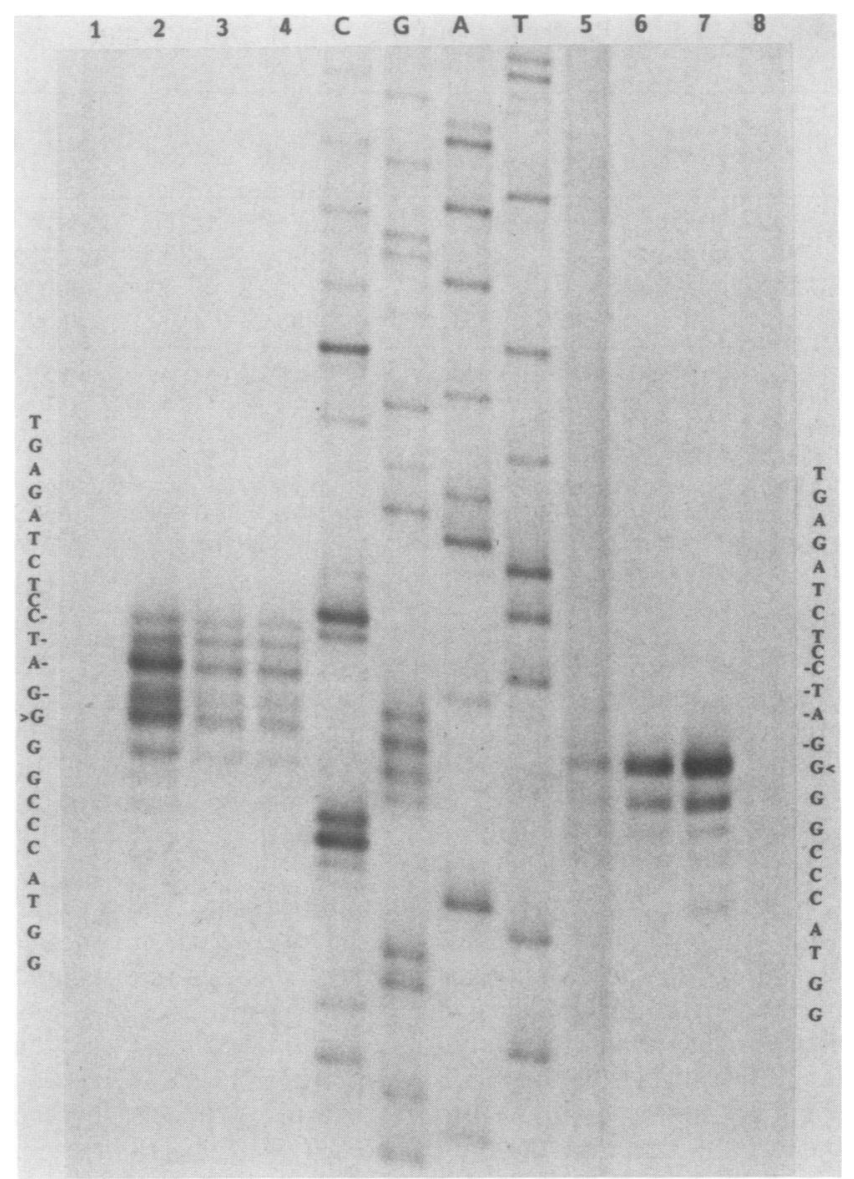

FIG. 4. Cleavage site of double-stranded M13mp19 DNA by PBCV-1-induced restriction endonuclease. M13mp19 +-strand DNA was sequenced by the dideoxy sequencing method (lanes $C$, $\mathrm{G}, \mathrm{A}, \mathrm{T})$, and ${ }^{35} \mathrm{~S}$-labeled, partially double-stranded M13mp19 DNA was synthesized by using the 15 -base universal primer preannealed with the single-stranded M13mp19 +-strand DNA and then digested with restriction endonucleases. The GATC sequence recognized by the PBCV-1-induced restriction endonuclease is indicated by bars $(-)$. Lanes 1 to 4 and 5 to 8 represent samples derived from ${ }^{35}$ S-labeled partially double-stranded M13mp19 DNA incubated with the PBCV-1-induced restriction endonuclease (lanes 4 and 5), $M$ boI (lanes 3 and 6), Sau3AI (lanes 2 and 7), or no restriction endonuclease (lanes 1 and 8). The partially double-stranded M13mp19 DNA used in lanes 5 to 8 was phenol extracted before restriction enzyme digestion, whereas the partially double-stranded M13mp19 DNA used in lanes 1 to 4 was not phenol extracted. The bands in lanes 2 to 4 and 5 to 7 which coincided with the $G$ are indicated by an arrowhead $(>)$.

tion endonuclease activity. Restriction endonuclease activity was not detected when cycloheximide was added at 30 min postinfection (Fig. 8B, lane 2 ). However, some enzyme activity was detected when cycloheximide was added at 60 and 90 min postinfection (lanes 3 and 4), and high levels were seen at $120 \mathrm{~min}$ (lane 5). The in vivo experiment suggests that de novo synthesis of a protein(s) required to degrade the host DNA begins between 30 and 60 min postinfection.

Restriction endonuclease is probably virus encoded. To determine whether the protein(s) required for host DNA degradation in vivo is encoded by the viral genome, total DNA was isolated from UV-irradiated cells infected with PBCV-1 and then analyzed on $\mathrm{CsCl}$ gradients. PBCV-1 can replicate, albeit much slower (ca. 16- to 20-h latent period) 


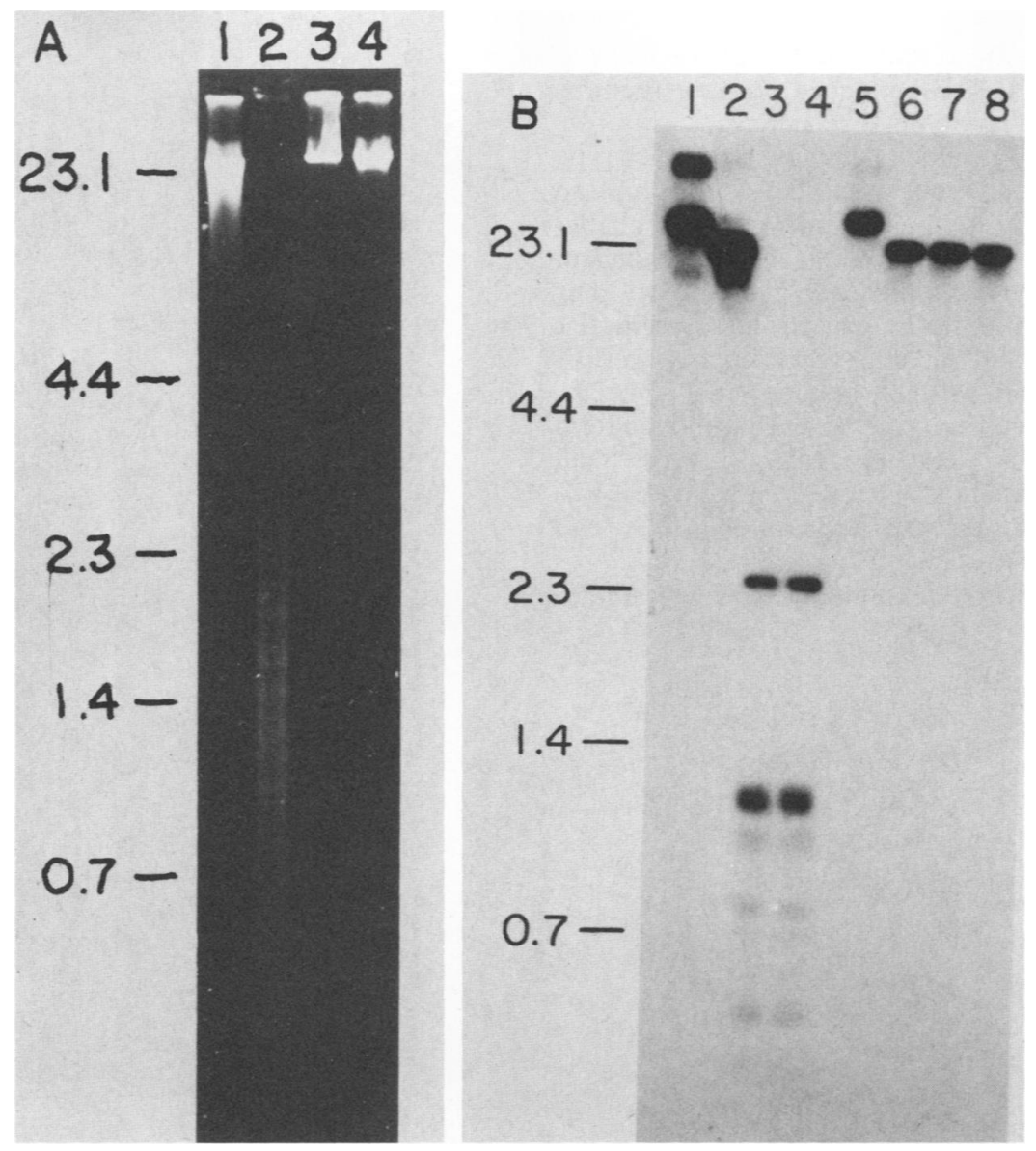

FIG. 5. (A) Sensitivity of Chlorella nuclear DNA and PBCV-1 DNA to PBCV-1-induced restriction endonuclease. Lanes: 1 , untreated host nuclear DNA; 2, host nuclear DNA treated with PBCV-1-induced enzyme; 3, untreated PBCV-1 DNA; 4, PBCV-1 DNA treated with PBCV-1-induced enzyme. Numbers on left are in kilobase pairs. (B) Effect of methylated bases on PBCV-1-induced restriction endonuclease activity. Plasmid pLG164, which contained a PBCV-1 BamHI DNA fragment (B6), was isolated from a dam dcm E. coli strain (lanes 1 to 4), and PBCV-1 genomic DNAs (lanes 5 to 8) were substrates for the enzyme. The Southern blot of the DNAs was probed with ${ }^{32}$ P-labeled PBCV-1 BamHI DNA fragment B6. Lanes: 1, plasmid pLG164; 2, plasmid pLG164 digested with BamHI; 3, plasmid pLG164 digested with Bam HI plus $\mathrm{MboI}$; 4, plasmid pLG164 digested with BamHI plus the PBCV-1-induced restriction endonuclease; 5, PBCV-1 DNA; 6, PBCV-1 DNA digested with BamHI; 7, PBCV-1 DNA digested with BamHI plus MboI; 8, PBCV-1 DNA digested with BamHI plus the PBCV-1-induced restriction endonuclease. Numbers on left are in kilobase pairs.

and with a small burst size (ca. 5 to 50 PFU), in cells previously exposed to $10 \mathrm{~min}$ of UV irradiation under the conditions described in the Materials and Methods (Van Etten et al., submitted for publication). These cells can no longer form colonies, and endogenous nucleic acid and protein syntheses are reduced to about background levels. Considerable degradation of host nuclear DNA occurred in virus-infected UV-irradiated cells by 4 h postinfection (Fig. 9A, trace C), and most of the host DNA was degraded by 8 $h$ postinfection (trace $E$ ). The amount of host DNA remained unchanged in uninfected UV-irradiated cells incubated for 8 h (trace B).

In a parallel experiment, enzyme extracts were prepared from UV-irradiated cells infected with PBCV-1 and examined for restriction endonuclease activity. Enzyme activity was detected in virus-infected UV-irradiated cells (Fig. 9B, lanes 2 to 4 ) but not in uninfected UV-irradiated cells (lane 1). The activity was detected by $4 \mathrm{~h}$ postinfection (Fig. 9B, lane 2) and was considerably higher after $8 \mathrm{~h}$ (lane 4). However, the level of activity was lower than that in
PBCV-1-infected, unirradiated cells at $3 \mathrm{~h}$ postinfection (Fig. 9B, lane 5). These results suggest that a PBCV-1-encoded protein(s) is required to degrade the host DNA in vivo. The appearance of the virus-induced restriction endonuclease activity coincides with the onset of host DNA degradation.

\section{DISCUSSION}

These results establish that PBCV-1 infection of Chlorella strain NC64A induces the synthesis of an enzyme with restriction endonuclease activity. Enzyme activity could first be detected about $1 \mathrm{~h}$ after infection, and the activity increased during viral replication. The appearance of the enzyme activity required de novo protein synthesis, and the enzyme was synthesized in UV-irradiated host cells infected with PBCV-1. Since UV-irradiation reduces host nucleic acid and protein syntheses to background levels, we believe the enzyme is probably virus encoded. However, conclusive proof will require identification of the restriction endonuclease gene.

Bacterial restriction endonucleases are classified as type I 
and type III if they require $\mathrm{Mg}^{2+}$, ATP, and $S$-adenosylmethionine or as type II if they require only $\mathrm{Mg}^{2+}$ for activity $(2,4,12,17)$. Since the PBCV-1-induced enzyme requires only $\mathrm{Mg}^{2+}$ for activity, it is a type II enzyme.

Even though the PBCV-1-induced enzyme resembles type II bacterial restriction endonucleases, the source of the enzyme is completely different. The enzyme is probably virus encoded and is isolated from a eucaryotic organism. Virus-encoded restriction endonuclease-like activity has previously been found in some $E$. coli strains carrying P1 prophage $(1,2,16)$ and in the blue-green alga Anacystis nidulans PCC6301 infected with the phage AS-1 $(24,25)$. Unlike the PBCV-1-induced enzyme, the AS-1-induced enzyme ultimately degrades substrate DNA to very small fragments. The bacteriophage P1-encoded enzyme (EcoPI), a type III restriction endonuclease, appears only in $E$. coli cells lysogenized by bacteriophage P1.

Although about 600 restriction endonucleases with a min-

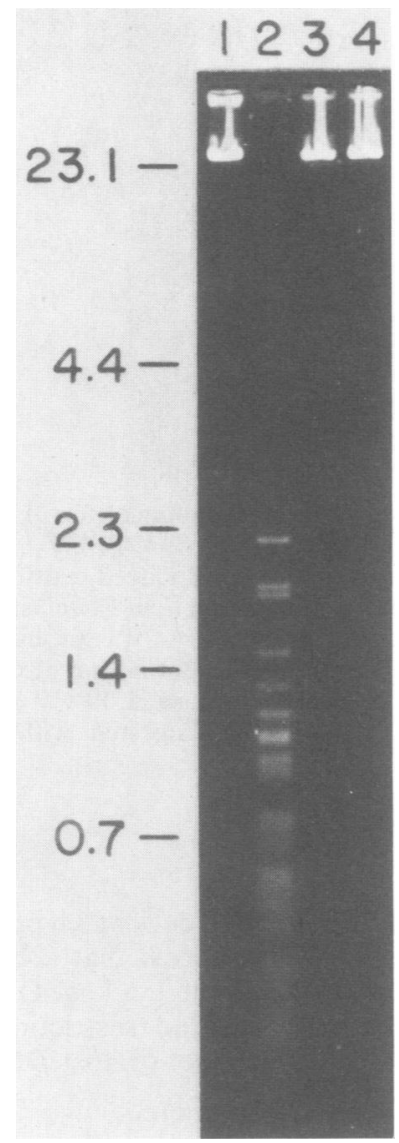

FIG. 6. Ability of dam methylase to protect DNA from cleavage by the PBCV-1-induced restriction endonuclease. Lambda DNA was methylated in vitro by incubating $1 \mu \mathrm{g}$ of DNA with $30 \mathrm{U}$ of dam methylase in $10 \mu \mathrm{l}$ of buffer $(50 \mathrm{mM}$ Tris hydrochloride [pH 7.5], 10 $\mathrm{mM}$ sodium EDTA, $5 \mathrm{mM} 2$-mercaptoethanol, $80 \mu \mathrm{M} S$-adenosylmethionine) for $1 \mathrm{~h}$ at $37^{\circ} \mathrm{C}$ followed by $20 \mathrm{~min}$ at $65^{\circ} \mathrm{C}$ to inactivate trace nucleases. The methylated products were then adjusted to contain $10 \mathrm{mM} \mathrm{MgCl} 2$ and cleaved in $40 \mu \mathrm{l}$ of assay buffer by the PBCV-1-induced restriction endonuclease. Lambda DNA was untreated (lane 1) or treated with the PBCV-1-induced restriction endonuclease (lane 2); lambda DNA after methylation by dam methylase was untreated (lane 3) or treated with the PBCV-1induced restriction endonuclease (lane 4). Numbers on left are in kilobase pairs.

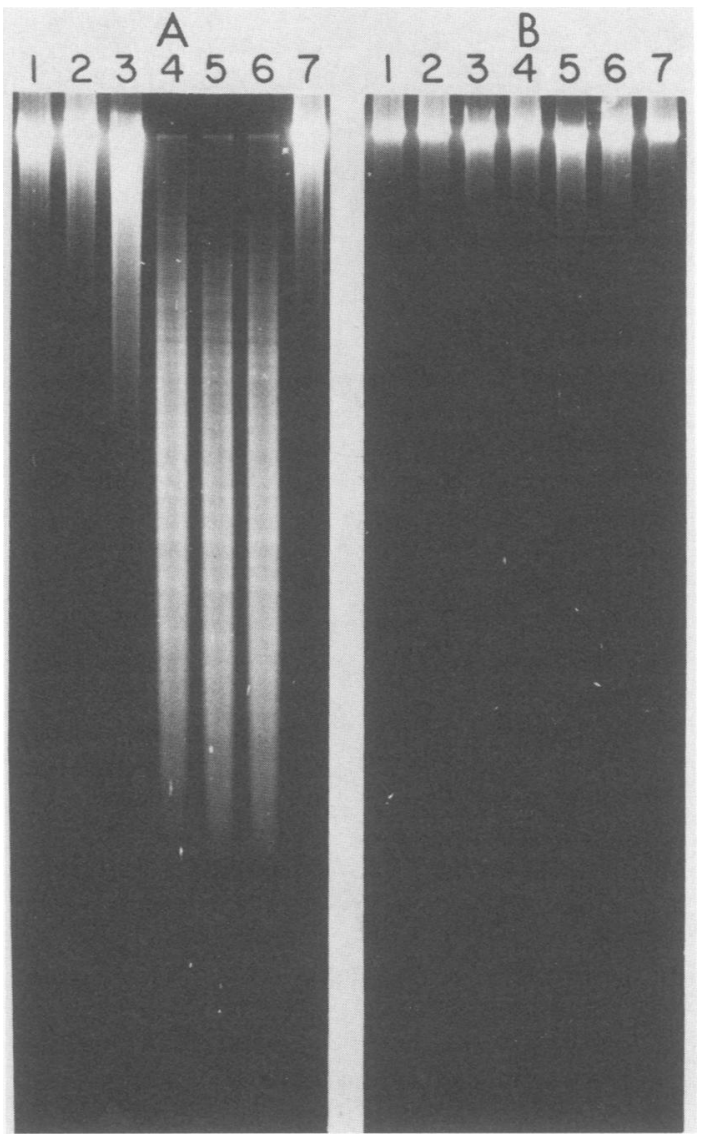

FIG. 7. Ability of enzyme extracts from uninfected and PBCV. 1-infected Chlorella cells to digest either host DNA (A) or PBCV-1 DNA (B). Enzyme extracts (fraction 2) were prepared from an equal number of uninfected or PBCV-1-infected cells and assayed for restriction endonuclease activity. A 5- $\mu$ l sample of each extract was incubated for $2 \mathrm{~h}$ with $1 \mu \mathrm{g}$ of either host nuclear DNA (A) or PBCV-1 DNA (B). The cleavage products were then electrophoresed on $1.2 \%$ agarose gels. Enzyme extracts were prepared from uninfected cells (lane 1), cells infected with PBCV-1 at zero time (lane 2), or cells $1 \mathrm{~h}$ (lane 3), $2 \mathrm{~h}$ (lane 4), $3 \mathrm{~h}$ (lane 5), or $4 \mathrm{~h}$ (lane 6 ) after infection. DNA in lane 7 was not treated. Note: enzyme extracts from 1-h- and, especially, 2- to 4-h-infected cells cleave host DNA but not PBCV-1 DNA.

imum of 116 different specificities have been found in a wide variety of procaryotes $(13,18)$, similar enzymes are rare in eucaryotes. A few DNA site-specific endonucleases have been reported in the yeasts Saccharomyces cerevisiae and Pichia membranaefaciens $(32,33)$ and the alga Chlamydomonas reinhardtii (6). However, these enzymes differ from restriction endonucleases in that they appear to lack a unique recognition sequence. The $\mathrm{PBCV}$-1-induced enzyme recognizes the sequence GATC and cleaves DNA 5' to the G as do several bacterial restriction endonucleases including MboI (8), Sau3AI (23), and DpnI (14). Similar to MboI, the PBCV-1-induced enzyme is inhibited by methylation of the internal deoxyadenosine in the GATC sequence. From an evolutionary standpoint it will be interesting to compare the genes encoding the bacterial restriction endonucleases which recognize GATC with that of the PBCV-1-induced enzyme.

The $\mathrm{PBCV}$-1-induced restriction endonuclease digested Chlorella nuclear DNA but not PBCV-1 DNA in vitro. We have previously shown that host nuclear DNA lacks $\mathrm{m}^{6} \mathrm{dA}$ in 


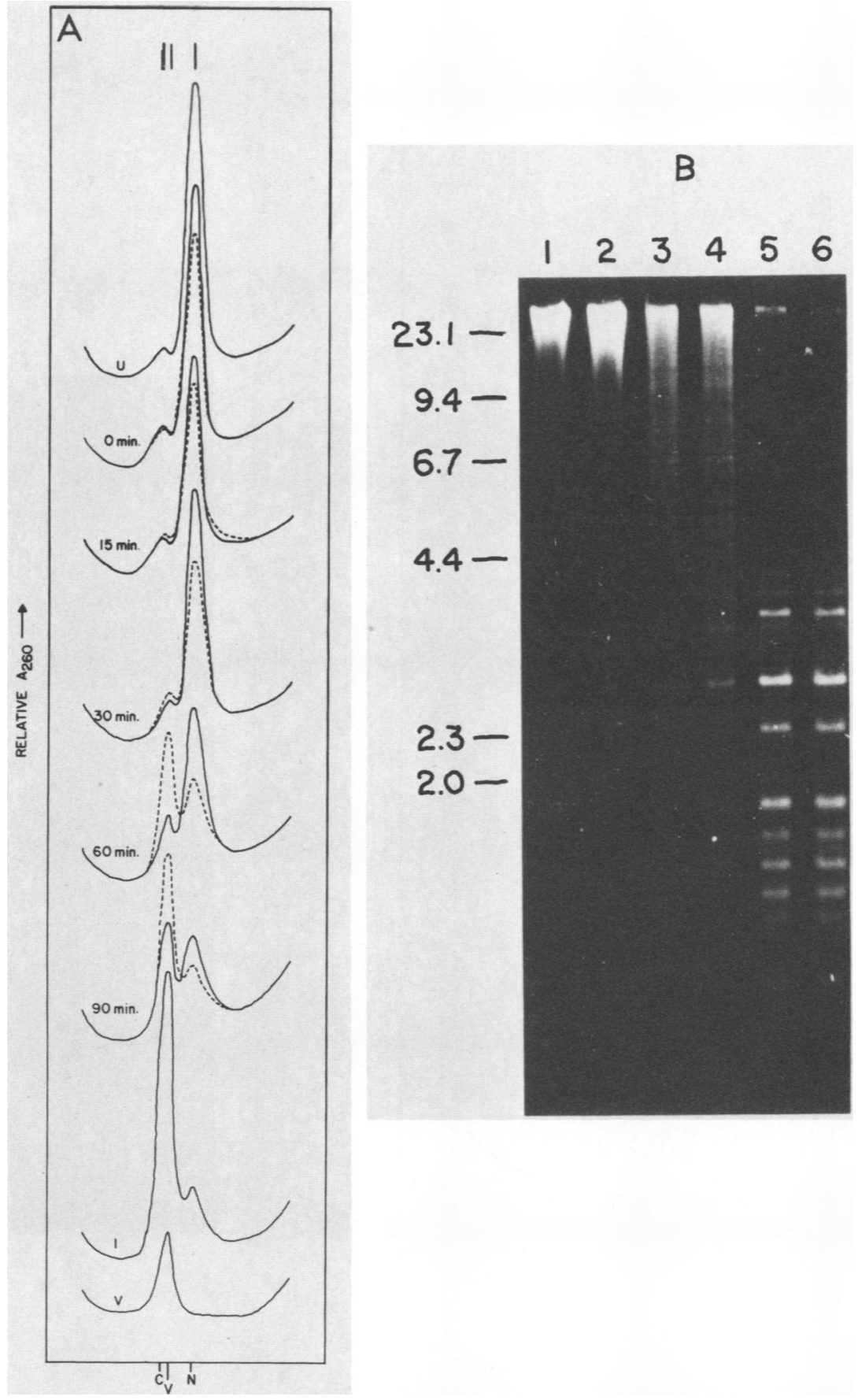

FIG. 8. Effect of cycloheximide on PBCV-1-induced degradation of the host nuclear DNA in vivo (A) and appearance of the PBCV-1-induced restriction endonuclease (B). (A) DNA was isolated from an equal number of cells at various times after infection with PBCV-1 and centrifuged to equilibrium in $\mathrm{CsCl}$ gradients. Cycloheximide $(25 \mu \mathrm{g} / \mathrm{ml})$ was added either at the same time as the virus $(0 \mathrm{~min})$ or at $15,30,60$, or $90 \mathrm{~min}$ after viral infection. The DNA was isolated either at the time of cycloheximide addition (solid lines) or at $4 \mathrm{~h}$ postinfection (dashed lines). The DNA band which increases with time is viral DNA. Trace $U$ is from uninfected cells, and trace $I$ is from 4-h-infected cells. Trace V is PBCV-1 DNA alone. Nuclear (N) DNA bands at about $1.72 \mathrm{~g} / \mathrm{ml}$, chloroplast (C) DNA bands at $1.69 \mathrm{~g} / \mathrm{ml}$, and viral (V) DNA bands at $1.70 \mathrm{~g} / \mathrm{ml}$. (B) Agarose gel assay of restriction endonuclease activity. Cycloheximide (25 $\mu \mathrm{g} / \mathrm{ml}) \mathrm{was}$ added either at the same time as the virus (lane 1) or at 30 (lane 2), 60 (lane 3), 90 (lane 4), or 120 min (lane 5) after viral infection. Lane 6 had no cycloheximide. All of the enzyme extracts (fraction 2) were prepared from an equal number of cells at $4 \mathrm{~h}$ postinfection and assayed for restriction endonuclease activity. A 5- $\mu$ l sample of each extract was incubated with $1 \mu \mathrm{g}$ of unmethylated lambda DNA at $37^{\circ} \mathrm{C}$ for $2 \mathrm{~h}$. The cleavage products were then electrophoresed on $1.2 \%$ agarose gels. Numbers on left are in kilobase pairs. 

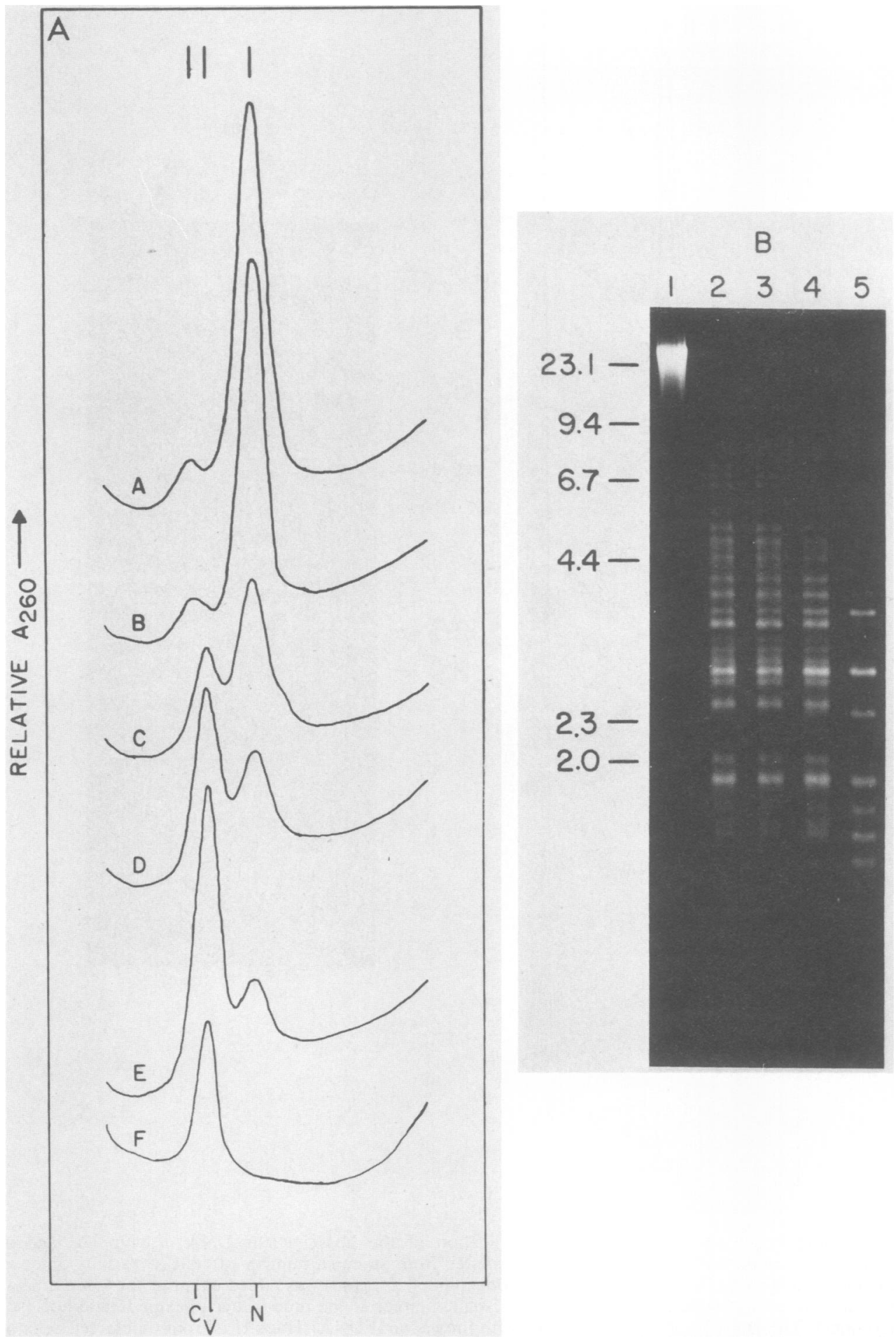

FIG. 9. Degradation of host nuclear DNA (A) and PBCV-1-induced restriction endonuclease activity (B) in UV-irradiated Chlorella cells infected with PBCV-1. (A) DNA was isolated from an equal number of UV-irradiated cells at various times after infection with PBCV-1 and centrifuged to equilibrium in $\mathrm{CsCl}$ gradients. Trace $\mathrm{A}$, Control cells; trace $\mathrm{B}$, uninfected UV-irradiated cells incubated for 8 h; and virus-infected UV-irradiated cells incubated for $4 \mathrm{~h}$ (trace C), $6 \mathrm{~h}$ (trace D), and $8 \mathrm{~h}$ (trace E). Trace F is PBCV-1 DNA. The positions of chloroplast (C), viral (V), and nuclear (N) DNA are indicated at the bottom of the figure. (B) Agarose gel assay of the restriction endonuclease activity. Enzyme extracts (fraction 2) were prepared from equal numbers of uninfected UV-irradiated cells incubated for $8 \mathrm{~h}$ (lane 1 ), virus-infected UV-irradiated cells incubated for $4 . \mathrm{h}$ (lane 2), $6 \mathrm{~h}$ (lane 3), and $8 \mathrm{~h}$ (lane 4), and virus-infected unirradiated cells incubated for $3 \mathrm{~h}$ (lane 5) and assayed for restriction endonuclease activity. A 5- $\mu$ l sample of each extract was incubated with $1 \mu \mathrm{g}$ of unmethylated lambda DNA at $37^{\circ} \mathrm{C}$ for $2 \mathrm{~h}$. The cleavage products were then electrophoresed on $1.2 \%$ agarose gels. Numbers on left are in kilobase pairs. 
the sequence GATC, whereas PBCV-1 DNA contains $\mathrm{G}^{\mathrm{m}} \mathrm{ATC}(30)$. As described in the following paper (34), the methyltransferase responsible for methylation of these adenosines has been detected in PBCV-1-infected cells. Both the PBCV-1-induced methyltransferase and the restriction endonuclease first appear about $1 \mathrm{~h}$ after PBCV-1 infection and recognize the same GATC base sequence. The appearance of these enzymes coincides with the initiation of PBCV-1 DNA synthesis and host DNA degradation (26). Thus, we propose that the two enzymes form a restriction and modification system which results in the selective degradation of the host DNA.

\section{ACKNOWLEDGMENTS}

We thank Martin Marinus for providing E. coli GM2163 and Anne Schuster, Lois Girton, Russel Meints, Les Lane, Myron Brakke, and Robert Blakesley for many helpful discussions.

This investigation was supported, in part, by Public Health Service grant GM-32441 from the National Institute of General Medical Sciences and grant DE-AC02-82ER12086 from the Department of Energy.

\section{LITERATURE CITED}

1. Bachi, B., J. Reiser, and V. Pirrotta. 1979. Methylation and cleavage sequences of the EcoPI restriction-modification enzyme. J. Mol. Biol. 128:143-163.

2. Bickle, T. A. 1982. The ATP-dependent restriction endonucleases, p. 85-108. In S. M. Linn and R. J. Roberts (ed.), Nucleases. Cold Spring Harbor Laboratory, Cold Spring Harbor, N.Y.

3. Boyd, J. B., and H. K. Mitchell. 1965. Identification of deoxyribonucleases in polyacrylamide gels following their separation by disk electrophoresis. Anal. Biochem. 13:28-42.

4. Boyer, H. W., E. Scibiensky, H. Slocum, and D. RoullandDussoix. 1971. The in vitro restriction of the replicative form of W.T. and mutant fd phage DNA. Virology 46:703-710.

5. Brown, T. L., M.-G. Yet, and F. Wold. 1982. Substratecontaining gel electrophoresis: sensitive detection of amylolytic, nucleolytic and proteolytic enzymes. Anal. Biochem. 122:164-172.

6. Burton, W. G., R. J. Roberts, P. A. Myers, and R. Sager. 1977. A site-specific single-strand endonuclease from the eukaryote Chlamydomonas. Proc. Natl. Acad. Sci. USA 74:2687-2691.

7. Geier, G. E., and P. Modrich. 1979. Recognition sequence of the dam methylase of $E$. coli $\mathrm{K} 12$ and mode of cleavage of DpnI endonuclease. J. Biol. Chem. 254:1408-1413.

8. Gelinas, R. E., P. A. Myers, and R. J. Roberts. 1977. Two sequence-specific endonucleases from Moraxella bovis. J. Mol. Biol. 114:169-179.

9. Hattman, S., J. E. Brooks, and M. Masurekar. 1978. Sequence specificity of the P1 modification methylase (M. EcoPI) and the DNA methylase (M. Ecodam) controlled by the E. coli dam gene. J. Mol. Biol. 126:367-380.

10. Jeppesen, P. G. N. 1980. Separation and isolation of DNA fragments using linear polyacrylamide gradient gel electrophoresis. Methods Enzymol. 65:305-319.

11. Karakashian, S. J., and M. W. Karakashian. 1965. Evolution and symbiosis in the genus Chlorella and related algae. Evolution 19:368-377.

12. Kauc, L., and A. Piekarowicz. 1978. Purification and properties of a new restriction endonuclease from Haemophilus influenzae Rf. Eur. J. Biochem. 92:417-426.

13. Kessler, C., P. S. Neumaier, and W. Wolf. 1985. Recognition sequences of restriction endonucleases and methylases-a review. Gene 33:1-102.
14. Lacks, S., and B. Greenberg. 1977. Complementary specificity of restriction endonucleases of Diplococcus pneumoniae with respect to DNA methylation. J. Mol. Biol. 114:153-168.

15. Marinus, M. G., M. Carraway, A. Z. Frey, L. Brown, and J. A. Arraj. 1983. Insertion mutations in the dam gene of Escherichia coli K-12. Mol. Gen. Genet. 192:288-289.

16. Meselson, M., and R. Yuan. 1968. DNA restriction enzyme from E. coli. Nature (London) 217:1110-1114.

17. Modrich, P., and R. J. Roberts. 1982. Type II restriction and modification enzymes, p. 109-154. In S. M. Linn and R. J. Roberts (ed.), Nucleases. Cold Spring Harbor Laboratory, Cold Spring Harbor, N.Y.

18. Roberts, R. J. 1985. Restriction and modification enzymes and their recognition sequences. Nucleic Acids Res. 13(Suppl.):r165-r200.

19. Rosenthal, A. L., and S. A. Lacks. 1977. Nuclease detection in SDS-polyacrylamide gel electrophoresis. Anal. Biochem. 80:76-90.

20. Sanger, F., A. R. Coulson, B. G. Barrell, A. J. H. Smith, and B. A. Roe. 1980. Cloning in single-stranded bacteriophage as an aid to rapid DNA sequencing. J. Mol. Biol. 143:161-178.

21. Schleif, R. 1980. Assaying of organisms for the presence of restriction endonucleases. Methods Enzymol. 65:19-23.

22. Skrdla, M. P., D. E. Burbank, Y. Xia, R. H. Meints, and J. L. Van Etten. 1984. Structural proteins and lipids in a virus, PBCV-1, which replicates in a Chlorella-like alga. Virology 135:308-315.

23. Sussenbach, J. S., R. Monfoort, R. Schiphof, and E. E. Stobberingh. 1976. A restriction endonuclease from Staphylococcus aureus. Nucleic Acids Res. 3:3193-3202.

24. Szekeres, M. 1981. Phage-induced development of a site-specific endonuclease in Anacystis nidulans, cyanobacterium. Virology 111:1-10.

25. Szekeres, M., A. E. Szmidt, and I. Torok. 1983. Evidence for a restriction/modification-like system in Anacystis nidulans infected by cyanophage AS-1. Eur. J. Biochem. 131:137-141.

26. Van Etten, J. L., D. E. Burbank, J. Joshi, and R. H. Meints. 1984. DNA synthesis in a Chlorella-like alga following infection with the virus PBCV-1. Virology 134:443-449.

27. Van Etten, J. L., D. E. Burbank, D. Kuczmarski, and R. H. Meints. 1983. Virus infection of culturable Chlorella-like algae and development of a plaque assay. Science 219:994-996.

28. Van Etten, J. L., D. E. Burbank, Y. Xia, and R. H. Meints. 1983. Growth cycle of a virus, PBCV-1, that infects Chlorella-like algae. Virology 126:117-125.

29. Van Etten, J. L., R. H. Meints, D. Kuczmarski, D. E. Burbank, and K. Lee. 1982. Viruses of symbiotic Chlorella-like algae isolated from Paramecium bursaria and Hydra viridis. Proc. Natl. Acad. Sci. USA 79:3867-3871.

30. Van Etten, J. L., A. M. Schuster, L. Girton, D. E. Burbank, D. Swinton, and S. Hattman. 1985. DNA methylation of viruses infecting a eukaryotic Chlorella-like green alga. Nucleic Acids Res. 13:3471-3478.

31. Wahl, G. M., M. Stern, and G. R. Stark. 1979. Efficient transfer of large DNA fragments from agarose gels to diazobenizyloxymethyl-paper and rapid hybridization by using dextran sulfate. Proc. Natl. Acad. Sci. USA 76:3683-3687.

32. Watabe, H., T. Shibata, and T. Ando. 1981. Site-specific endodeoxyribonucleases in eukaryotes: endonucleases of yeasts, Saccharomyces and Pichia. J. Biochem. 90:1623-1632.

33. Watabe, H., T. Shibata, T. lino, and T. Ando. 1984. Purification of a eukaryotic site-specific endonuclease, Endo.SceI, from Saccharomyces cerevisiae and effectors on its specificity and activity. J. Biochem. 95:1677-1690.

34. Xia, Y., and J. L. Van Etten. 1986. DNA methyltransferase induced by PBCV-1 virus infection of a Chlorella-like green alga. Mol. Cell. Biol. 6:1440-1445. 